\title{
A CRITICAL REVIEW OF THE CURRENT CHECKLIST OF BUT- TERFLIES OF SERBIA
}

\author{
PREDRAG JAKŠIĆ́ ${ }^{1, \star}$ \\ ${ }^{1}$ Faculty of Natural Sciences and Mathematics, University of Priština, Kosovska Mitrovica, Serbia
}

\begin{abstract}
The latest checklist of butterflies of Serbia (Papilionoidea Latreille, 1802) by Popović \& Verovnik (2018) is examined. In consistencies with regard to the cited literature and applied systematics are pointed out. The validity of the viewpoints of the above mentioned authors on the species Leptidea juvernica Williams, 1946, Pyrgus trebevicensis (Warren, 1926), Erebia manto (Denis Schiffermüller, 1775) and Melitaea ornata Christoph, 1893 is discussed. It is shown that by imposing new Serbian names to butterflies disregards national and scientific heritage.
\end{abstract}

Keywords: Butterflies, Papilionoidea, Republic of Serbia.

\section{INTRODUCTION}

In the Republic of Serbia, two checklists of butterflies of Serbia have been published in which, besides their scientific names, their local vernacular names are given (Jakšić \& Đurić, 2008; Jakšić et al., 2013). Recently, a third checklist was published (Popović \& Verovnik, 2018). Thanks to these texts, the knowledge about the fauna of this group of insects in Serbia is gradually being completed. We can safely claim that new species of butterflies in Serbia will be determined. Firstly, there will be those that are present in neighboring countries, and then the invasive species that are spreading from the south towards the north. Here in, we want to look at the above mentioned text of Popović \& Verovnik (2018).

\section{A CRITICAL REVIEW OF THE CHECKLIST OF POPOVIĆ AND VEROVNIK (2018)}

In their introduction, the authors emphasize that during the compilation of the checklist, 166 references with data on the fauna of the butterflies of Serbia were used, starting from the first work of Frivaldszky (1877). The authors are unaware of earlier works, such as Marsili (1726), who provided the first notes on the butterflies of Vojvodina. After Marsili, and before Frivaldszky (1877), two papers on the butterflies of Serbia were published too. The aforementioned 166 works are given at the end in two lists (with many spelling mistakes), but it is not clear on what principle: what is the difference between the "References" list and the "Supplementary" list when some of the works appear on both lists? Most probably the second list should have been titled "Bibliography of Serbian Butterflies"? In fact, according to our data, there are 410 published works on the butterflies of Serbia, with an additional 20 graduate and master's theses.

The systematic list of butterflies applied by the authors poses a dilemma. Nieukerken et al. (2011), as well as subsequent relevant authors (De Prins, 2016; Aarvik et al., 2017; Leveque et al., 2017), in the superfamily Papilionoidea Latreille, 1802 in first place give the family Papilionidae Latreille, 1802, and then the family Hesperiidae Latreille, 1809. In their paper, the authors have switched the places of these families. Similarly, Popović and Verovnik place the family Riodinidae Grote, 1895 after the family Lycaenidae Leach, 1885, while in Nieukerken et al. (2011) the order was the reverse. It is not known from whom this systematics was taken, since in the introductory part the authors only cite the literature sources for taxonomy and nomenclature, referring to the informal site of Fauna Europaea (Karsholt van Nieukerken, 2013).

Attention is given to the species Leptidea morsei (Fenton, 1882). This species has not been found in Serbia for almost 80 years (Miloš Rogulja found 50 4oin the period 19201939). Rogulja found the specimens on the so-called "Futoški drum"-a $7 \mathrm{~km}$-long road that linked Novi Sad and Futog. Since then, this habitat has disappeared due to urbanization; however, corresponding habitats still exist in the immediate vicinity of the Fruška Gora slopes. Lorković (1993) pointed out that the habitat of L. morsei in Croatia is defined by the community of Lathyretoquercetum petraeae HR-T 1957; an equivalent community of Quercetum confertae-cerris Rudski 1939 is represented on Fruška Gora. Plants on which caterpillars feed are present there. Of the 16 species of the genus Lathyrus L., 1753 in the flora of Vojvodina, 15 are present in the flora of Fruška Gora (Boza et al., 2003). The species Lathyrus niger (L.) Bernth.1800 is present at 14 localities, including localities on Fruška Gora. The species Lathyrus vernus (L.) Bernh.1800 is present at 17 localities in Vojvodina, among them 12 are on Fruška Gora. Both Lathyrus species, which are important for the survival of Leptidea morsei, are present in the flora of Fruška Gora. The real problem is that after Rogulja, this species of butterflies on Fruška Gora has not been comprehensively studied.

The value of this checklist is to provide a position with regard to several dubious taxa. Summarizing their results, we can

\footnotetext{
^ Corresponding author: jaksicpredrag@gmail.com
} 
say that there is little probability of the presence in Serbia of the species Colias chrysotheme (Esper, 1781), Polyommatus escheri (Hübner, 1823), Hipparchia fatua Freyer, 1843 and Melanargia russiae (Esper, 1783).The survival of these and some other species in Serbia is conditioned by a combination of ecological factors in the relevant habitats. By examining the material that was handled and published by Csipe (2006), Popović \& Verovnik (2018) correctly concluded that this is a wrong determination, that in fact it is the species C. erate (Esper, 1805). However, we believe that the possibility of the presence of this species in Serbia should not be completely ruled out. Kovács (1956) gave a detailed account of its distribution. The author states that in the Collection of the Hungarian Natural History Museum he found a pair of this species from Zavidovići (Bosnia and Herzegovina). It is probable that this species can be found in Serbia in favorable years. As a food plant for caterpillars, Astragalus austriacus Jacq.1762 is present at several localities in Vojvodina and around Belgrade (Diklić et al., 1972; Knežević et al., 2012). In this case as well, the problem is that no one has specifically focused on this species, which is very similar to C. crocea.

There is less likelihood of finding Polyommatus escheri (Hübner, 1823). Monophagous caterpillars seek the species Astragalus monspessulanus, represented in Serbia by the taxon $A$. monspessulanus L. subsp.illyricus (Bernh.) Chater. Fragmented subpopulations were found at Sukovo sites: Vera (Jerma River gorge) and Petačinci (Tomović, 2009). P. escheri (Hübner, 1823) is present in neighboring countries Montenegro, FYR Macedonia and Bulgaria (Kudrna et al., 2015).

A group of dubious taxa with insufficiently defined status is particularly interesting. This group consists of species that are characterized by various terms: bad species (Descimon \& Mallet, 2009), sibling species (Mayer, 1942); cryptic species complex (Dincã et al., 2013). In Serbia, several pairs of this group are important. The question of the differentiation of Leptidea sinapis and L. juvernica has been open for a long time. Descimon \& Mallet (2009) treat them as sibling species. In practice, the separation is based on differences in the length of the aedeagus and saccus. However, Neumayer Segerer (1995) and later on Cupedo \& Wim Hoen (2006) concluded that there is continuity in the statistical sample of the analyzed parameters. Coutsis (2013) also provided confirmation of continuity. Analysis of the number of chromosomes showed the existence of polymorphism. Undoubtedly, the species L. sinapis $(\mathrm{n}=29)$, L. morsei $(\mathrm{n}=54)$, L. amurensis ( $\mathrm{n}=61)$ and L. duponcheli $(\mathrm{n}=104)$ constitute an aneuploid array (Federley, 1938; Lorković, 1949, 1990; Maeki, 1958).On the other hand, an analysis of the number of chromosomes in the Palearctic area, from Spain towards Kazakhstan in the case of L. sinapis, has shown that this number gradually decreases, from $2 n=106$ in Spain to $2 \mathrm{n}=56-64$ in Kazakhstan.

In the absence of a better method, separation is routinely based on these parameters, with the addition of the appropriate wing characteristics (Cuvelier \& Maertens, 2017).Thanks to the work of Hauser (1997), for the determination of our material we have adopted a table of borderline values, as shown here in (Table 1, Fig. 1, Fig. 2).

Table 1. Relation between aedeagus and saccus length in $L$. sinapis and L. reali (according to Hauser, 1997).

\begin{tabular}{|l|l|l|}
\hline & Aedeagus $(\mathrm{mm})$ & Saccus $(\mathrm{mm})$ \\
\hline L. sinapis & $1.65-1.90$ & $0.80-0.90$ \\
\hline L. reali & $1.70-2.10$ & $0.70-0.85$ \\
\hline
\end{tabular}

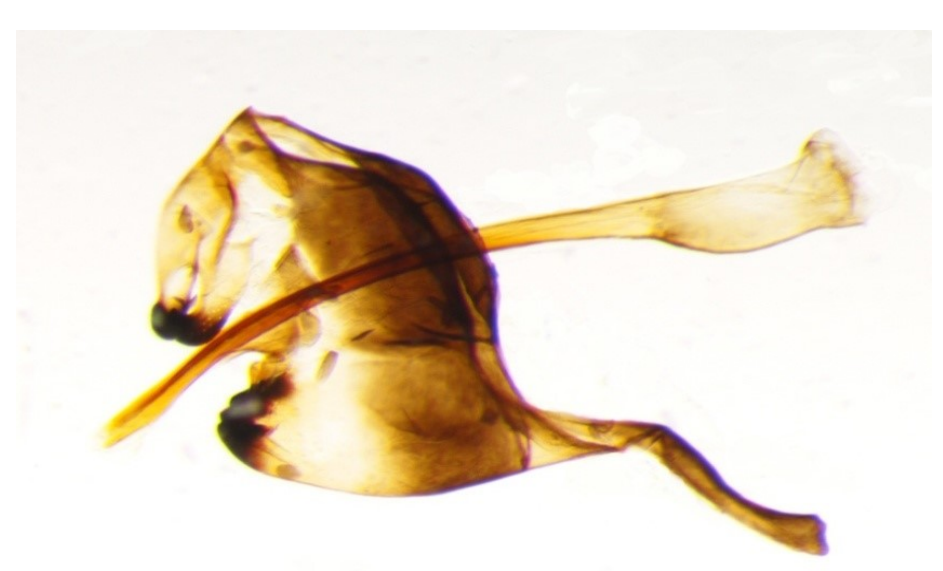

Figure 1. Leptidea juvernica Williams, 1946. Male genitalia. Serbia, Rudnik Mt., 600 m, 440’ 26” N; 20³0’00” E, 28. April 1985., Jakšić P. leg et coll.

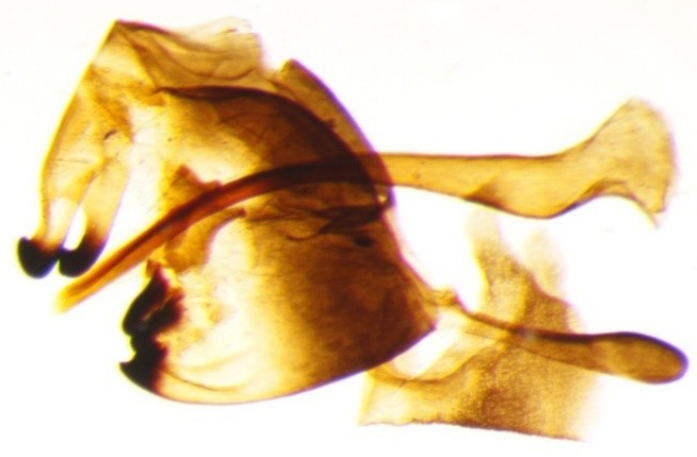

Figure 2. Leptidea sinapis Linnaeus, 1758. Male genitalia. Serbia, Vidlič; Mt., Crni Vrh, 1046 m, 43 10' 51” N; 22 38' 52” E, 29. May 2015., Nahirnić A. leg et coll.

At the time, no difference had been established between $L$. reali and $L$. juvernica, but we can now use these values for the taxon L. juvernica. Of around 200 samples of the L. sinapis group in our collection, we have made 163 preparations of genital armatures. In this material, there were only 17 specimens $(10 \%)$ belonging to the species L. juvernica from the territory of Serbia, as shown in Table 2. 
Table 2. Results of biometric analysis of saccus (SAC) and aedeagus (AED) in L. sinapis and L. juvernica.

\begin{tabular}{|c|c|c|}
\hline \multicolumn{3}{|c|}{ Leptidea juvernica Williams, 1946} \\
\hline \multirow[t]{2}{*}{ SLIDE No. \& PLACE } & SAC & AED \\
\hline & $(\mathrm{mm})$ & $(\mathrm{mm})$ \\
\hline SR-2711: Jadovnik Mt., Milošev Do & 0.8 & 1.8 \\
\hline SR-2330: Tara Mt., Beli Rzav & 0.85 & 1.8 \\
\hline SR-2306: Kosmaj & 0.7 & 1.75 \\
\hline SR-2102: Paštrik Mt., Gorožup & 0.6 & 1.8 \\
\hline SR-2314: Tutin, Crkvine & 0.75 & 1.7 \\
\hline SR-5740: Priština, Grmija Mt. & 0.65 & 1.7 \\
\hline SR-2123: Bor, Savača & 0.7 & 1.7 \\
\hline SR-2338: Zlatibor Mt., Mokra Gora & 0.8 & 2 \\
\hline SR-2102: Šar-Planina Mt., Izgorenica & 0.7 & 1.7 \\
\hline SR-2048: Bor, Mali Krivelj & 0.8 & 1.75 \\
\hline SR-2683: Jadovnik Mt., Kašanj & 0.7 & 1.6 \\
\hline SR-2125: Bor, Mali Krivelj & 0.75 & 1.9 \\
\hline SR-2328: Tara Mt., Rača River canyon & 0.8 & 1.85 \\
\hline SR-2337: Tara Mt., Kaluđerske Bare & 0.8 & 1.9 \\
\hline SR-2336: Užice, Đetinja River gorge & 0.85 & 1.9 \\
\hline SR-2312: Divčibare & 0.75 & 1.8 \\
\hline SR-1786: Rudnik Mt. & 0.75 & 1.95 \\
\hline \multicolumn{3}{|c|}{ Leptidea sinapis (Linnaeus, 1758) } \\
\hline SR-6763: Peć, Rugovska klisura gorge & 0.6 & 1.4 \\
\hline SR-2313: Tutin, Crkvine & 0.65 & 1.65 \\
\hline SR-2677: Prijepolje, Mileševka river gorge & 0.55 & 1.75 \\
\hline SR-2493: Niš, Jelašnička klisura gorge & 0.55 & 1.5 \\
\hline SR-2406: Zasavica & 0.55 & 1.5 \\
\hline SR-2619: Divčibare & 0.6 & 1.5 \\
\hline SR-2618: Divčibare & 0.65 & 1.5 \\
\hline SR-2600: Stara Planina, Babin Zub & 0.6 & 1.55 \\
\hline SR-2599: Prijepolje, Mileševka river gorge & 0.55 & 1.55 \\
\hline SR-2598: Jadovnik Mt., Sopotnica & 0.65 & 1.6 \\
\hline SR-2304: Kosmaj Mt. & 0.6 & 1.7 \\
\hline SR-2311: Divčibare & 0.65 & 1.65 \\
\hline SR-2307: Ritopek & 0.65 & 1.6 \\
\hline SR-2299: Negotin & 0.65 & 1.65 \\
\hline SR-2303: Bor, Dubašnica & 0.6 & 1.5 \\
\hline SR-2305: Tutin, Crkvine & 0.6 & 1.55 \\
\hline SR-2302: Negotin, Dupljane & 0.65 & 1.55 \\
\hline SR-2384: Fruška Gora Mt., Grabovo & 0.6 & 1.6 \\
\hline SR-2076: Šar-Planina Mt., Rečane & 0.65 & 1.6 \\
\hline SR-2405: Fruška Gora Mt., Beočin & 0.6 & 1.55 \\
\hline SR-2072: Mokra Gora Mt., Istok & 0.65 & 1.5 \\
\hline SR-2046: Bor, Savača & 0.65 & 1.5 \\
\hline SR-2301: Negotin & 0.55 & 1.6 \\
\hline SR-2716: Vidlič Mt., Crni Vrh & 0.6 & 1.6 \\
\hline
\end{tabular}

There is continuity in the size of both analyzed parameters, as pointed out by the abovementioned authors (Table 2).To distinguish species, characters that can be reliably determined are considered, regardless of whether they are morphological, physiological/biochemical, ecological or otherwise. This is the practical aspect of making concrete differentiations among related species. Lorković (1928) proved that the species are complexly differentiated. Consequently, in closely related species it is not enough to rely solely on one parameter. In practice, the desired goal is most often achieved using two or more parameters. In our case, the differentiation between L. sinapis and L. juvernica can be illustrated using two analyzed parameters (Table 2). If the position of the saccus and aedeagus of each individual specimen is given in a graph in the form of a point, we obtain the result shown in Fig. 3.

Using this method, we can determine the largest number of samples. But statistically, there will always be some that cannot be separated in this way; new parameters are then used. In our case, this could be the color of the apex of the fore-wings.Namely, by examining about 200 samples in our collection, we noticed that the color in L. juvernica is gray-black, while in L. sinapis it is black-black. The difference is insignificant, but constant and easily observed.

The taxonomic status of the species Pyrgus trebevicensis (Warren, 1926) is still uncertain. Depending on the viewpoint of individual authors, it is considered either to be a species or a subspecies. Jakšić (2011) treats this taxon as a species. His argument is in the clearly distant appearance of the valves in three related taxons: armoricanus, alveus and trebevicensis (Jakšić, 2011, Fig. 1). The application of molecular/genetic methods will contribute to a clarification of the status. Many taxa were long treated as subspecies, only to be proven at some point to be species.

It is surprising that the authors, on no scientific basis, excluded the species Erebia manto (Denis Schiffermüller, 1775) from the fauna of Serbia, arguing that the locality where it was found is not in Serbia, but in Montenegro. They offer no evidence for this claim. Jakšić \& Pešić (1995) provided convincing information about its presence. The species was found on the Serbian side of the mountain pass, Čakor (Fig. 4). Not long ago it was found on the Montenegrin side of the Čakor Pass (Franeta, 2018).

The history of nomenclature changes in the Melitaea phoebe-species group is a turbulent one. Jakšić (2011) described it as a new one for Serbia under the then valid name, Melitaea telona (Fruhstorfer, 1908). Later, Russell \& Tennent (2016) described all the nomenclature ambiguities within this species group. Accordingly, the species $M$. ornata Christoph, 1893 replaced the aforementioned M. telona species in Serbia. At the time, the authors expressed doubts about Jakšić's (2011) data on the presence of $M$. ornata Christoph, 1893 in Serbia. In that time, according to Tóth and Varga (2010), main identification parameter wa the depth of the central notch of the saccus. Jakšić determine M. telona on the basis of this parameter. Later, Tóth (2012) pointed that discriminative characters are the lunules in the marginal region of underside of hind-wings and ring form of the club of the antennae. Therefore, herein we provide additional arguments confirming the presence of the species in Serbia (Figs. 5, 6 and 7). 


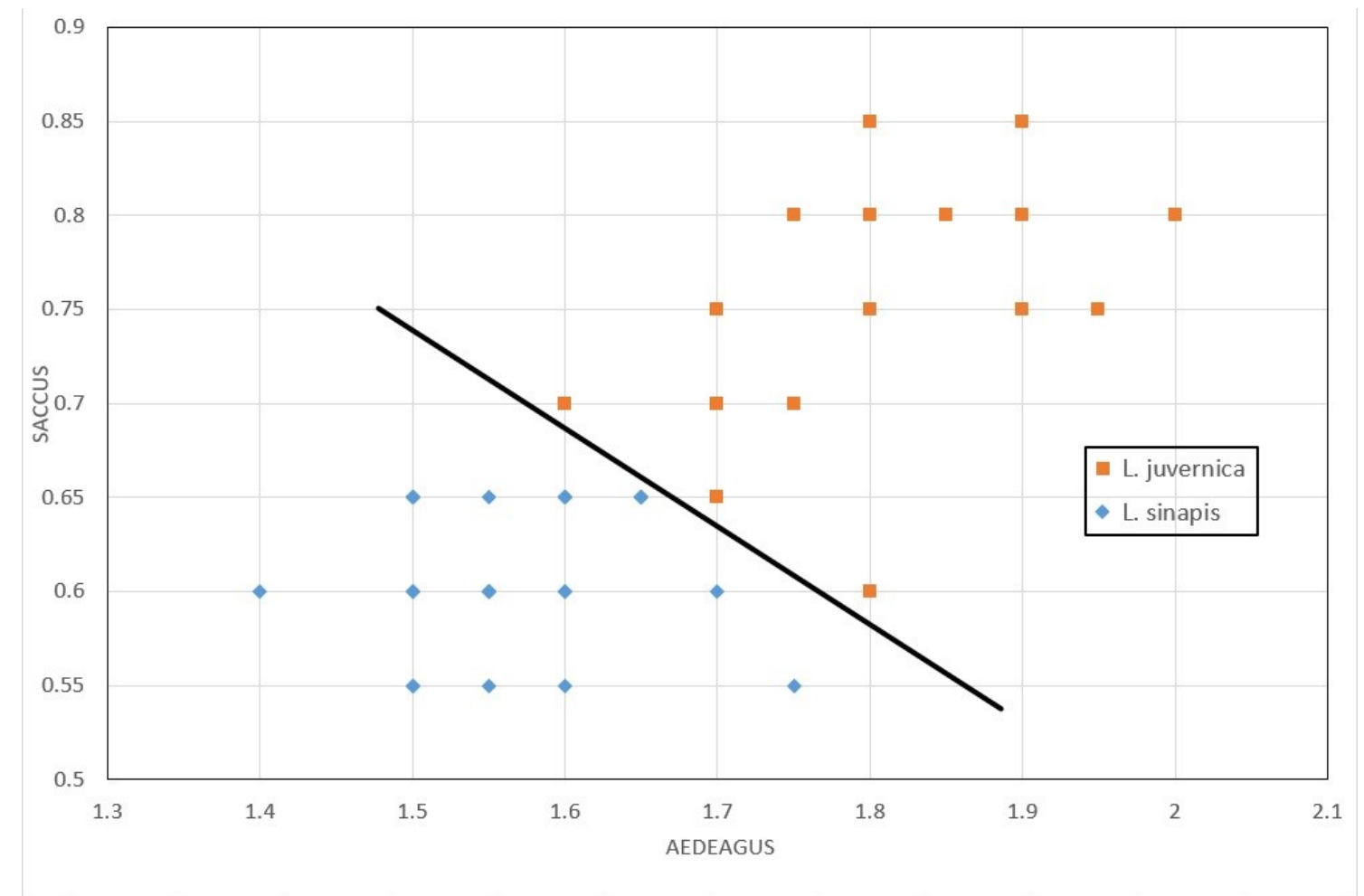

Figure 3. Degree of differentiation between L. sinapis and L. juvernica on the base on saccus and aedeagus

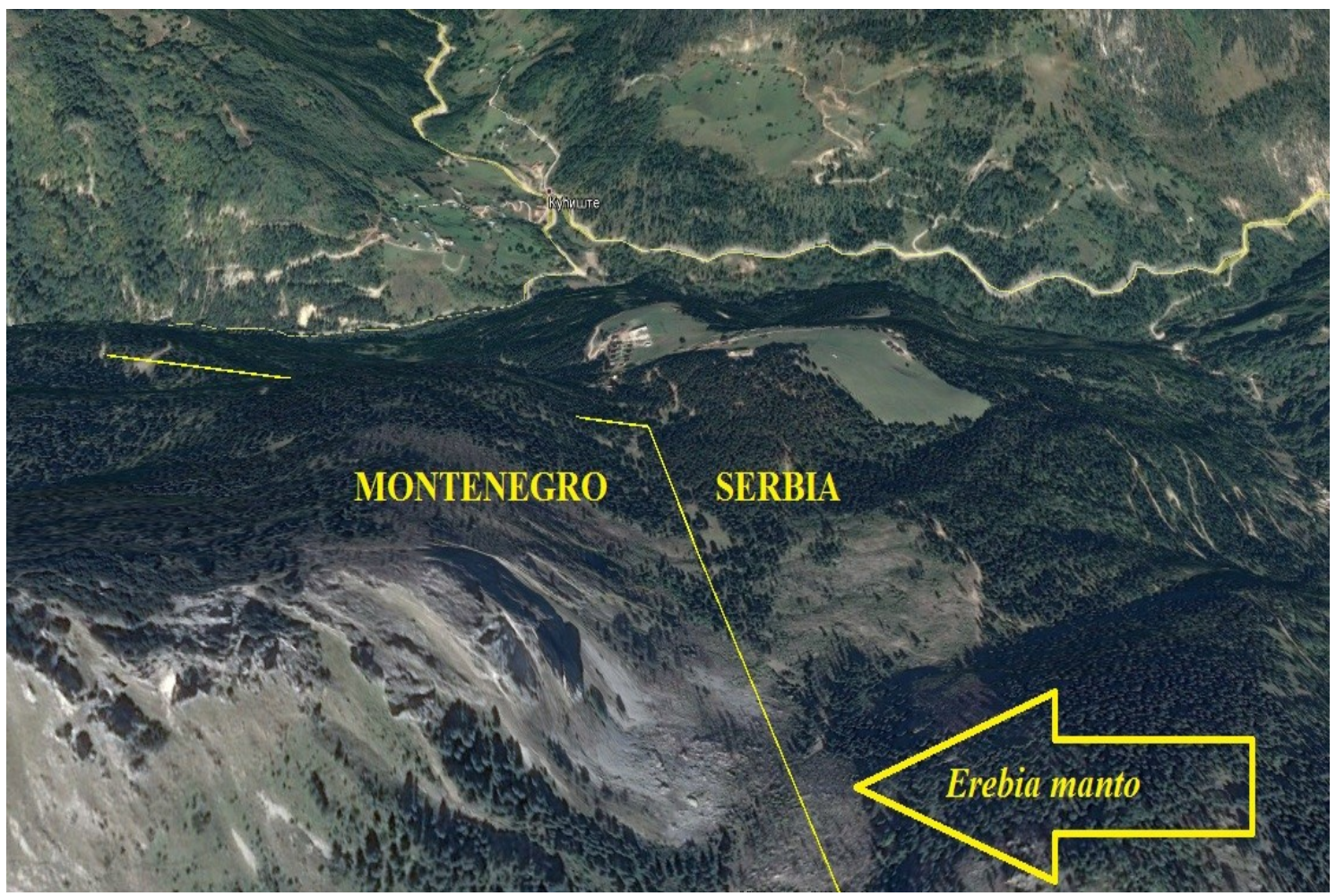

Figure 4. Collecting place of E. manto in Serbia on Čakor Pass, 1794 m; 4240’18” N; 20 05’ 15” E. (map source: Google Earth)

The attached Serbian names of butterflies deserve special attention. Language is certainly one of the foundations of every nation. National identity is first reflected in language. Language builds on the culture of a people, preserving its national character, its history.It is a tradition of western European nations to carefully nurture their national terminology for plants, fungi and animals. For example, in English terminology, the vernacular names used by Lewin (1795) Tortoiseshell (Nymphalis polychloros), Peacock (Inachis io), Chalkhill Blue (Lysandra coridon), and many others, are unchanged and in still use after more than two centuries. 


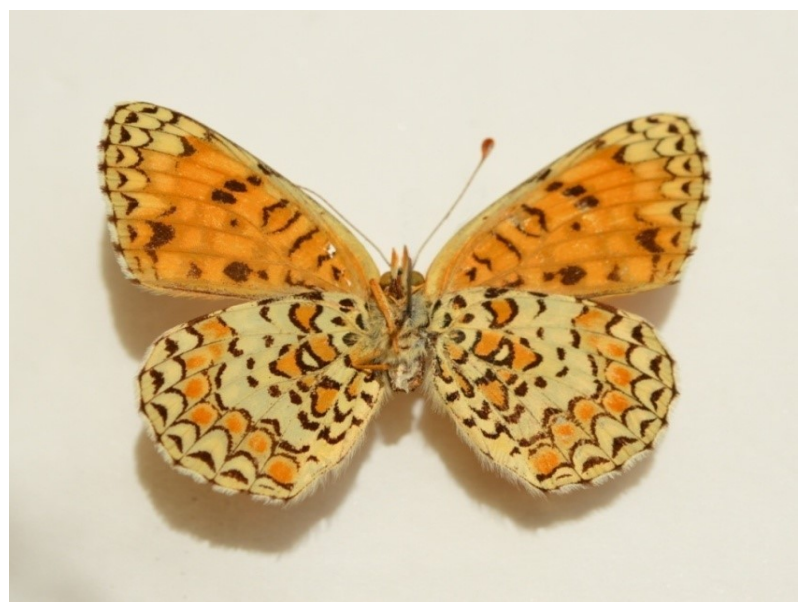

Figure 5. Melitaea ornata Christopg, 1893. Serbia, Kačanik (Đeneral Janković), $490 \mathrm{~m}$; 42 $2^{\circ} 14$ '26” N; 21 14' 28” E, 18. May 1979., Jakšić P. leg et coll.

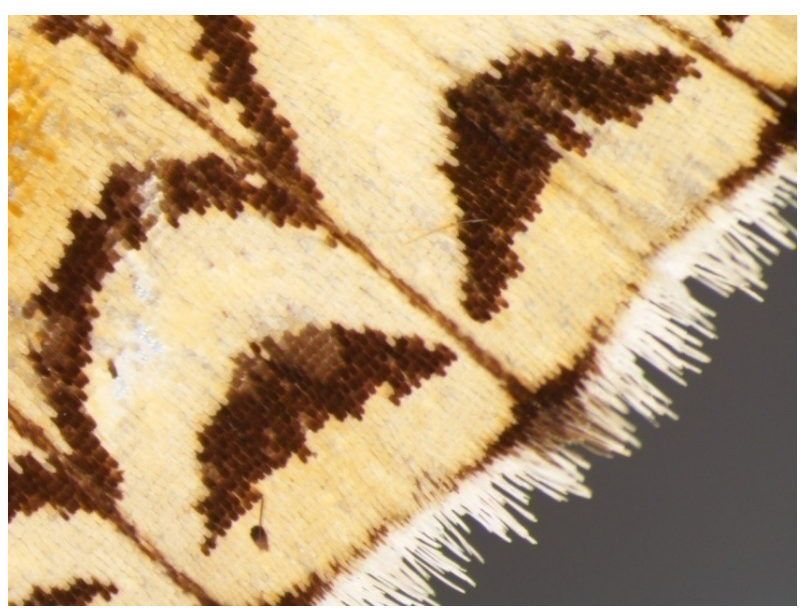

Figure 6. The same specimen, detail of hind-wing: triangle like lunules as a discriminative characters.

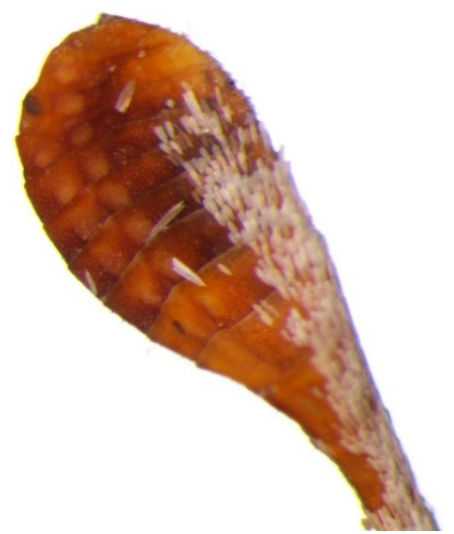

Figure 7. The same specimen, the club of the antennae, ring form as a discriminative characters.

Carl Linnaeus' assigning of scientific names was a wise move. He incorporated already existing names from his predecessor. For butterflies, for example, he took over many of the names used by Aldrovandi (1602): Papilio, minimus, Pyrausta, Pyrallis, Geometra, Bombyce, pityocampa and many others. Thanks to this, the continuity of names was maintained for four centuries, which is of invaluable educational value.

The tradition of using Serbian names for butterflies is more than two centuries old. It dates from the translation of the notable work Naturgeschichte für Kinder (Raff, Georg Christian, 1783) (Vujić, 1809). In his translation, Vujić gave Serbian names to species. Consequently, this work is part of national heritage, and it is protected by the Constitution of the Republic of Serbia, Article 89: "Everyone is obliged to protect natural rarities and scientific, cultural and historical heritage, as well as goods of public interest in accordance with the Law".

Just before his death, Josif Pančić left the following request to the Serbian Royal Academy, that... "in the records of our Academy, the purity of our beautiful language be preserved, just as the people have given us and as our great teachers V. Karađić and Đ .Daničić prescribed” (Novaković, 2011).

The first list of Serbian names for butterflies was published by Jakšić \& Đurić (2008) and included the 193 species known at the time. On the identification of new species in the fauna of Serbia and discovering old works from the period 1809-1941, another list was published (Jakšić et al., 2013). These lists supplemented the first list, without changing the names. An analytical review of the introduction of Serbian names, with the inventory up to the period before the Second World War, was presented by Jakšić (2017). The above works are known to Popović and Verovnik, but they have completely ignored them and introduced new vernacular names. It should be highlighted that this presents a third variant of the names, with numerous differences compared to the previous two (Popović \& Đurić, 2011, 2014), and it creates complete confusion: not only are the scientific and cultural heritage ignored, but their own previously assigned names are refused. This cannot be considered valid scientific language.

\section{CONCLUSIONS}

Traditional entomological methods have established a solid knowledge of species in the fauna of Serbian butterflies. We have confirmed the presence of the species Melitaea ornata Christoph, 1893 in Serbia. We have pointed out that the species Erebia manto (Denis Schiffermüller, 1775) is also a member of the fauna of Serbia. Questions regarding dubious taxa from the group of bad species remain unanswered. For the most part, these questions can be resolved by using modern molecular/genetic methods, such as barcoding, etc. Additionally, it is possible to expect the finding of some rare species that exist in Serbia's neighboring countries. Likewise, several invasive species, also present in the countries neighboring Serbia, can be expected to be found. Thus, we believe that the checklist of butterflies of Serbia will soon number over 200 species. 


\section{ACKNOWLEDGEMENTS}

I am thankful to Milan Dubljanin for valuable assistance and Ana Nahirnić for useful advices.

\section{REFERENCES}

Aldrovandi, U. 1602. De animalibvs insectis libri septem: cum singulorum iconibus ad viuum expressis. In Bonon [Bologna] apud Ioan Bapt Bellagambam.

Boza, P., Igić, S. R., Krstić, B., et al. 2003. Distribution of the Lathyrus L. 1753 (Fabales, Fabaceae) species in the Vojvodina Province. Zbornik Matice srpske za prirodne nauke, 104, pp. 61-81. doi:10.2298/zmspn0304061b.

Coutsis, G. J. 2013. Leptidea sinapis and Leptidea reali (Lepidoptera: Pieridae):at what point does the first one of the two end, and the other one begin. Phegea, 41(1), pp. 19-20, 1 tab. with 18 figs.

Csipe, T. 2006. The Insect Collection of the Municipial Museum in Subotica. Museion, 5, pp. 229-272, 2 tabs, 23 figs. [In Serbian, Hungaryan and English summary].

Cupedo, F. \& Wim Hoen, F. 2006. Leptidea sinapis and Leptidea reali (Lepidoptera: Pieridae) in The Netherlands. Entomologische Berichten 66(4): 118-123, 4 tabs, 7 figs.

Cuvelier, S. \& Maertens, D. 2017. Trial test of external morphology-based identification of Leptidea sinapis, L. reali and L. juvernica (Lepidoptera: Pieridae) provides opportunity for an online identification platform. Phegea 45(2): 41-45, 4 figs.

Descimon, H. \& Mallet, J. 2009. Bad species. In J. Settele, M. Konvicka, T. Shreeve, R. Dennis, D. H. Van Eds., Ecology of Butterflies in Europe. Cambridge University Press. pp. 219-249.

Diklić, N., Cincović, T., \& Kojić, M. 1972. Red Fabales. In M. Josifović Ed., Flora SR Srbije. Beograd: SANU. IV, pp. 254-558, figs. [In Serbian].

Dincã, V., Wiklund, C., Lukhtanov, V., et al. 2013. Reproductive isolation and patterns of genetic differentiation in a cryptic butterfly species complex. Journal of Evolutionary Biology, 26(10), pp. 2095-2106. doi:10.1111/jeb.12211.

Federley, H. 1938. Chromosomenzahlen finnlän-discher lepidopteren. Hereditas, 24(4), pp. 397-464. doi:10.1111/j.16015223.1938.tb03219.x.

Franeta, F. 2018. Checklist of the butterflies (Lepidoptera: Papilionoidea) of Montenegro. Zootaxa, 4392(1), p. 128. doi:10.11646/zootaxa.4392.1.6.

Hauser, E. 1997. Leptidea sinapis (Lennaeus, 1758) und Leptidea reali Reissinger 1989: zwei verschieden Arten? (Lepidoptera, Pieridae). Beitr. Naturk. Oberösterreichs, 5, pp. 65-755 figs.

Jakšić, P. 2011. Butterfly species (Lepidoptera; Hesperioidea and Papilionoidea) new to the Serbian fauna. Biologia Nyssana, 2, pp. 45-50.

Jakšić, P., Petrović, S., \& Nahirnić, A. 2013. Compendium of Serbian butterflies with vernacular names. Bulletin of the Natural History Museum, 6, pp. 75-88. doi:10.5937/bnhmb1306075j.
Jakšić, P. \& Pešić, B. 1995. The distribution of certain Erebia species in Serbia (Lepidoptera, Satyridae) / Rasprostranjenje nekih Erebia vrsta u Srbiji (Lepidoptera, Satyridae). Univerzitetska misao, Prirodne nauke: Priština, 2(1), pp. 23-26, 1996.

Jakšić, P. \& Đurić, M. 2008. Srpski nazivi dnevnih leptira (Lepidoptera: Hesperioidea i Papilionoidea). (Serbian Names for Butterflies). In Proceeding of the 9th Symposium of flora of Southeastern Serbia and Neighbouring Regions. Niš. pp. 231237.

Knežević, A., Džigurski, D., Ljavnaić-Mašić, B., \& Čupina, B. 2012. Plant cover of pasture ecosystem located in the vicinity of Muzlja, Serbia. Ratarstvo i povrtarstvo, 49(1), pp. 39-45. doi:10.5937/ratpov49-1204.

Kovács, L. 1956. Some Data Concerning the Subspecific Distribution of Colias chrysotheme Esp. (Lepidoptera). Annals HNHM, Budapest, 48, pp. 425-434.

Kudrna, O., Pennerstorfer, J., \& Lux, K. 2015. Distribution Atlas of European butterflies and skippers. Verlag Peks / K., Schwanfeld.

Lewin, W. 1795. The papilios of Great Britain : Systematically arranged, accurately engraved, and painted from nature with the natural history of each species ... /.London: Smithsonian Institution. doi:10.5962/bhl.title.48880.

Lorković, Z. 1928. Analiza pojma i varijabiliteta vrste na osnovi ispitivanja nekih Lepidoptera. Glasnik hrvatskoga prirodoslovnoga društva, Zagreb, XXXIX I XL, pp. 1-64.

Lorković, Z. $1949 . \quad$ ChromosomenzahlenVervielfachung bei Schmetterlingen und einr Fall fün $_{a}$ cherZah.RevueS uissedezoologie, 56(4), pp.243`249, 4 figs.

Lorković, Z. 1990. The butterfly chromosomes and their application in systematic and phylogeny. In Kudrna Ed., Butterflies of Europe. 2. Introduction to Lepidopterology. Wiesbaden: AULA Verlag. pp. 332-396.

Lorković, Z. 1993. Ecological association of Leptidea morsei major Grund 1905 (Lepidoptera, Pieridae) with the oak forest Lathyretoquercetum petraeae HR-T 1957 in Croatia. Periodicum Biologorum 95(4): 455-457.

Maeki, K. 1958. On the cytotaxonomical relationship in Leptidea (Lepidoptera - Rhopalocera). The Japanese journal of genetics, 33(9), pp. 283-285. doi:10.1266/jjg.33.283.

Mayer, E. 1942. Systematics and the origin of species. New York: Columbia University Press.

Novaković, S. 2011. . Negovanje jezika Srpskog, poslanica Akademiji nauka filosofskih. Srpska Kraljevska Akademija. Glas, X, pp. 1-88. Beograd. [In Serbian].

Popović, M. \& Verovnik, R. 2018. Revised checklist of the butterflies of Serbia (Lepidoptera: Papilionoidea). Zootaxa, 4438(3), p. 501. doi:10.11646/zootaxa.4438.3.5.

Popović, M. \& Đurić, M. 2011. Dnevni leptiri Srbije. Priručnik. Beograd: HabiProt. 198 pp.

Popović, M. \& Đurić, M. 2014. Dnevni leptiri Stare planine (Lepidoptera: Papilionoidea) / Butterflies of Stara Planina (Lepidoptera: Papilionoidea). Beograd: Srbijašume; Beograd: HabiProt. 208 pp. 
Russell, P. \& Tennent, W. J. 2016. A synonymic list of names 33-43, 6 figs.

associated with western Palaearctic Melitaea phoebe (Denis Tóth, P. J. 2012. Taxonomy, distribution and ecology of Melitaea oramp; Schiffermüller, 1775) species group taxa (M. phoebe; nata (Lepidoptera: Nymphalidae).Debrecen: Debreceni Egyetem. M. punica Oberthür, 1876; M. ornata Christoph, 1893) (Lepi- pp. 1-117, Dissertation.

doptera, Nymphalidae). Nota Lepidopterologica, 39(1), pp. 27-56. Vujić, J. 1809. Jestestvoslovije v polzu najpače junosti. Budim: doi:10.3897/nl.39.5929.

Pečatano pri Slaveno-Serbskoi Pečatni Kral. Vseučilišta Venger-

Tomović, G. 2009. Threat status revision of some taxa from "The Red Data Book of Flora of Serbia 1". Botanica Serbica, 33(1), pp. skago. (translation from German, original: Raff, Georg Christian, 1783. Naturgeschichte für Kinder. Göttingen). 